Original Paper

\title{
Wirausaha Produktif Berbasis Sektor Unggulan Desa Senyiur Lombok Timur
}

\author{
Sukardi $^{1 *}$, Burhanuddin ${ }^{2}$, Lalu Ali Wardana ${ }^{3}$, Hamidsyukrie ZM ${ }^{4}$ \\ ${ }^{1}$ Fakultas Keguruan dan Ilmu Pendidikan \& Pascasarjana, Universitas Mataram, Indonesia \\ ${ }^{234}$ Fakultas Keguruan dan Ilmu Pendidikan, Universitas Mataram, Indonesia
}

DOI: $10.29303 /$ jpmpi.v2i1.350

Sitasi: Sukardi, Burhanuddin, Wardana, L. A., ZM, H. (2019). Wirausaha Produktif Berbasis Sektor Unggulan Desa Senyiur Lombok Timur. Jurnal Pengabdian Magister Pendidikan IPA (JPMPI). (2) 1. pp. 37-42

*Corresponding Author: Sukardi, Fakultas Keguruan dan Ilmu Pendidikan \& Pascasarjana, Universitas Mataram, Indonesia; Email: sukardi@unram.ac.id

\begin{abstract}
Pengabdian ini dilakukan karena berangkat dari tiga kondisi yang dihadapi kelompok sasaran (kelompok usia produktif, anak putus sekolah/tidak melanjutkan studi, buat aksara), yaitu: (1) lemahnya skill dalam menghasilkan produk berbasis keunggulan wilayah, padahal potensi keunggulan sangat potensial baik dibidang pertaninan, peternakan, perdagangan, kerajinan, jasa, dan lainnya; (2) belum memadainya kemampuan dalam pengelolaan usaha berbasis keunggulan wilayah, baik tata kelola keuangan, tata kelola kelembagaan, manajemen sumber daya, maupun lainnya; dan (3) belum memadainya kemampuan dalam memasarkan produk termasuk strategi bersaing. Kondisi ini berimplikasi terhadap pendapatan yang masih rendah, daya beli masyarakat, produktivitas, dan angka kemiskinan yang masih tinggi. Oleh karenanya, pengabdian ini dilakukan dengan tujuan untuk memperkuat kompetensi kelompok sasaran dalam mengembangkan usaha ekonomi produktif berbasis sektor unggulan wilayah. Untuk mewujudkan tujuan tersebut, maka solusi yang ditawarkan adalah berupa kegiatan pelatihan dan pendampingan wirausaha produktif pada tiga aspek sekaligus, yaitu: pengembangan produk, pengelolaan usaha, dan pemasaran. Pelaksanaan pelatihan dan pendampingan dilakukan melalui kaji tindak partisipatif dengan pendekatan andragogis yang mengedepankan brainstorming dan praktik. Hasil pengabdian menunjukkan bahwa kelompok sasarn memliki kompetensi yang memadai dalam mengembangkan wirausaha produktif, khususnya dalam bidang peternakan dan pengolahan makanan hasil pertanian. Hasil pendampingan juga menunjukkan adanya ada 1 (satu) kelompok peternak yang sudah mengimplementasikan hasil pelatihan disamping 1 (satu) kelompok yang mengembangkan pengolahan makanan hasil pertanian. Dibalik capaian tersebut, hal yang perlu diapresiasi adalah adanya keinginan, semangat, dan motivasi kelompok sasaran untuk mengembangkan usaha produktif.
\end{abstract}

Kata Kunci: Wirausaha Produktif, Unggulan Desa

\section{Pendahuluan}

Desa Senyiur merupakan salah satu dari 13 Desa di Kecamatan Keruak dengan luas wilayah mencapai 5,27 KM atau $23 \%$ dari total luas Kecamatan Keruak (BPS, 2018). Untuk mencapai desa ini, dapat ditempuh melalui perjalanan darat maupun laut. Perjalanan darat dalam kondisi normal dari Kota Mataram (Ibu Kota Provinsi) dapat ditempuh selama kurang lebih 1 jam 40 menit dengan jarak $64 \mathrm{~km}^{2}$. Sementara itu, perjalanan darat dalam kondisi normal dari Selong (Ibu Kota Kabupaten Lombok Timur) dapat ditempuh selama kurang lebih 40 menit dengan jarak $20 \mathrm{~km}^{2}$ (BPS Lombok Timur, 2018b)

Jumlah penduduk di Desa ini mencapai 3.486 jiwa yang tergabung dalam 1.012 Rumah Tangga. Dilihat dari jenis kelamin, penduduk berkelamin perempuan mendominasi yang mencapai 1.922 orang (BPS Lombok Timur, 2018b). Dari jumlah tersebut, sebagian besar bekerja pada sektor pertanian, baik pemilik, penggarap, maupun buruh 
tani. Selain itu, peternakan, perdagangan, home industry, dan jasa juga mewarnai aktivitas ekonomi masyarakat di Desa ini.

Namun demikian, permasalahan ekonomi masih menjadi permasalahan krusial yang dihadapi masyarakat Desa Senyiur Kecamatan Keruak Kabupaten Lombok Timur. Paling tidak ada beberapa indikator yang menunjukkannya, yaitu: jumlah penduduk miskin, garis kemiskinan, indeks kedalaman kemiskinan (P1), indeks keparahan kemiskinan (P2), struktur pekerjaan dan kualitas pekerjaan. Jumlah penduduk Miskin di Kabupaten Lombok Timur mencapai $18,46 \%$ atau 216.180 orang (BPS Lombok Timur, 2018a). Sementara itu garis kemiskinan di Kabupaten Lombok Timur baru menyentuh Rp. 382.861. Data ini menempatkan Kabupaten lombok Timur sebagai kabupaten tertinggi jumlah penduduk yang miskin. Kondisi ini sangat memperihatinkan jika dilihat dari target MDGs 2015 yang menetapkan garis kemiskinan sampai $10 \%$ dengan menggunakan acuan garis kemiskinan nasional yang setara dengan USD 1,50 (PPP).

Dilihat dari indikator indeks kedalaman kemiskinan (P1), di Kabupaten Lombok Timur mencapai 2,88 yang tentu saja termasuk didalamnya adalah Desa Senyiur (BPS Lombok Timur, 2018a). P1 ini menunjukkan ukuran ratarata kesenjangan pengeluaran masing-masing penduduk miskin terhadap batas kemiskinan, di mana semakin tinggi nilai indeks ini maka semakin besar rata-rata kesenjangan pengeluaran penduduk miskin terhadap garis kemiskinan. Dengan demikian, tingginya nilai-nilai indeks kedalaman kemiskinan (P1) di Desa Senyiur menunjukkan kehidupan ekonomi penduduk miskin semakin terpuruk.

Selanjutnya, dilihat dari indeks keparahan kemiskinan (P2) di Kabupaten Lombok Timur mencapai angka 0,68 (BPS Lombok Timur, 2018a). Data ini menunjukkan adanya ketimpangan ketimpangan pengeluaran di antara penduduk miskin di Kabupaten Lombok Timur, termasuk di Desa Senyiur. P2 pada dasarnya memberikan gambaran mengenai penyebaran pengeluaran diantara penduduk miskin. Dengan demikian, kemiskinan seolah menjadi lingkaran setan yang menghantui masyarakat di kawasan Desa Senyiur.

Permasalahan krusial adalah banyaknya penduduk usia produktif yang menganggur yang disumbangkan oleh anak yang putus sekolah, tidak melanjutkan studi, dan penduduk buta aksara. Hasil observasi lapangan, terdapat 64 orang anak yang tidak melanjutkan studi karena berbagai faktor, seperti ekonomi, minat, budaya, dan lainnya sebagaimana pernah diungkap Sukardi (2010). Selain itu, masih terdapat 460 orang penduduk kategori buta aksara (Profil Desa Senyiur, 2017) yang berimplikasi terhadap masih tingginya angka kemiskinan.

Disisi lain Desa ini memiliki sektor unggulan pada pertanian, peternakan, perdagangan, home industry, dan kerajinan. Luas wilayah pertanian mencapai $452 \mathrm{Ha}$ (19\%) dari total luas lahan pertanian di Kecamatan Keruak. Padi, jagung, tembakau, cabai, tomat, kacang hijau menjadi komoditas unggulan pada sektor pertanian bahan makanan. Permasalahannya adalah sumber daya petani. Masih rendahnya kualitas sumberdaya manusia pertanian merupakan kendala yang serius yang dihadapi. Rata-rata mereka berpendidikan rendah, bahkan banyak yang tidak mengenyam pendidikan. Di sektor peternakan, sapi, kambing, kerbau, ayam, menjadi andalan peternakan di Desa ini. Dalam dua tahun terakhir, sektor peternakan di kecamatan Keruak (termasuk desa Senyiur) menunjukkan trend peningkatan, dari 12,479 ternak pada Tahun 2015 meningkat menjadi 12,732 pada tahun 2016 (BPS Lombok Timur, 2018b). permsalahannya adalah peternakan yang masih dilakukan secara tradisional dan sambilan. Peternak biasanya memelihara ternaknya secara sederhana dan menggantungkan pada keramahan alam. Belum ada upaya kearah pengembangkan peternakan yang efisien, terintegrasi dengan pertanian berskala besar serta berbasis sumber daya lokal. Permasalahan pemasaran komoditas peternakan juga menjadi permasalahan lain yang mesti menjadi perhatian. Harga ternak di Desa ini masih rendah. Kondisi ini diperparah dengan impor daging dengan harga yang sangat murah. Di sektor kerajinan, terdapat potensi kerajinan perhiasan, kerajinan kayu, kerajinan dari bambu, kerajinan kain tenun dan lainnya. Namun demikian, potensi ini belum dikelola dengan baik untuk menguak kemajuan masyarakat di Desa ini. Disisi lain, lembaga ekonomi seperti Bumdes, karang taruna, koperasi, kelompok home industri dan lainnya belum mampu menjadi penopang pengembangan usaha bagi masyarakat kawasan. Permasalahan krusial yang dihadapi adalah permasalahan manajemen pengelolaan usaha 
termasuk pemasaran usaha. Pemasaran masih lingkup kawasan, tidak memanfaatkan berbagai media yang tersedia. Tidak ada strategi pemasaran melalui personal selling, promosi, tempat, maupun strategi pemasaran dari sisi harga.

Atas kondisi ini, maka diperlukan intervensi penguatan ekonomi melalui pelatihan dan pendampingan wirausaha. Lee dan Peterson (2000) menyebutkan entrepreneurship sebagai faktor signifikan daya saing bangsa (lulusan), karena entrepreneurship merupakan agen utama penggerak perubahan ekonomi (Wong dkk., 2005; Acs \& Amoros, 2008; Koelinger \& Thurik, 2012). Untuk menumbuhkan entrepeneurship, maka dibutuhkan lingkungan enterpreneurial (Schulte, 2004; Wong dkk., 2007; Etzkowitz \& Zhou, 2008), yang menggerakkan semua komponen masyarakat untuk bergerak dalam menciptakan bisnis atau usaha baru berdasarkan potensi yang dimiliki masyarakat. Tesis ini dibuktikan secara empiris melalui kajian Sukardi dkk. (2014) dengan kelompok sasaran anak putus sekolah.

\section{Metode Pelaksanaan}

Solusi yang ditawarkan dalam pengabdian ini adalah melakukan pelatihan dan pendampingan wirausaha produktif berbasis sektor unggulan wilayah (pengembangan produk, pengelolaan usaha, dan strategi pemasaran). Sasaran utama adalah kelompok penduduk usia produktif, khususnya penduduk yang putus sekolah atau tidak melanjutkan studi.

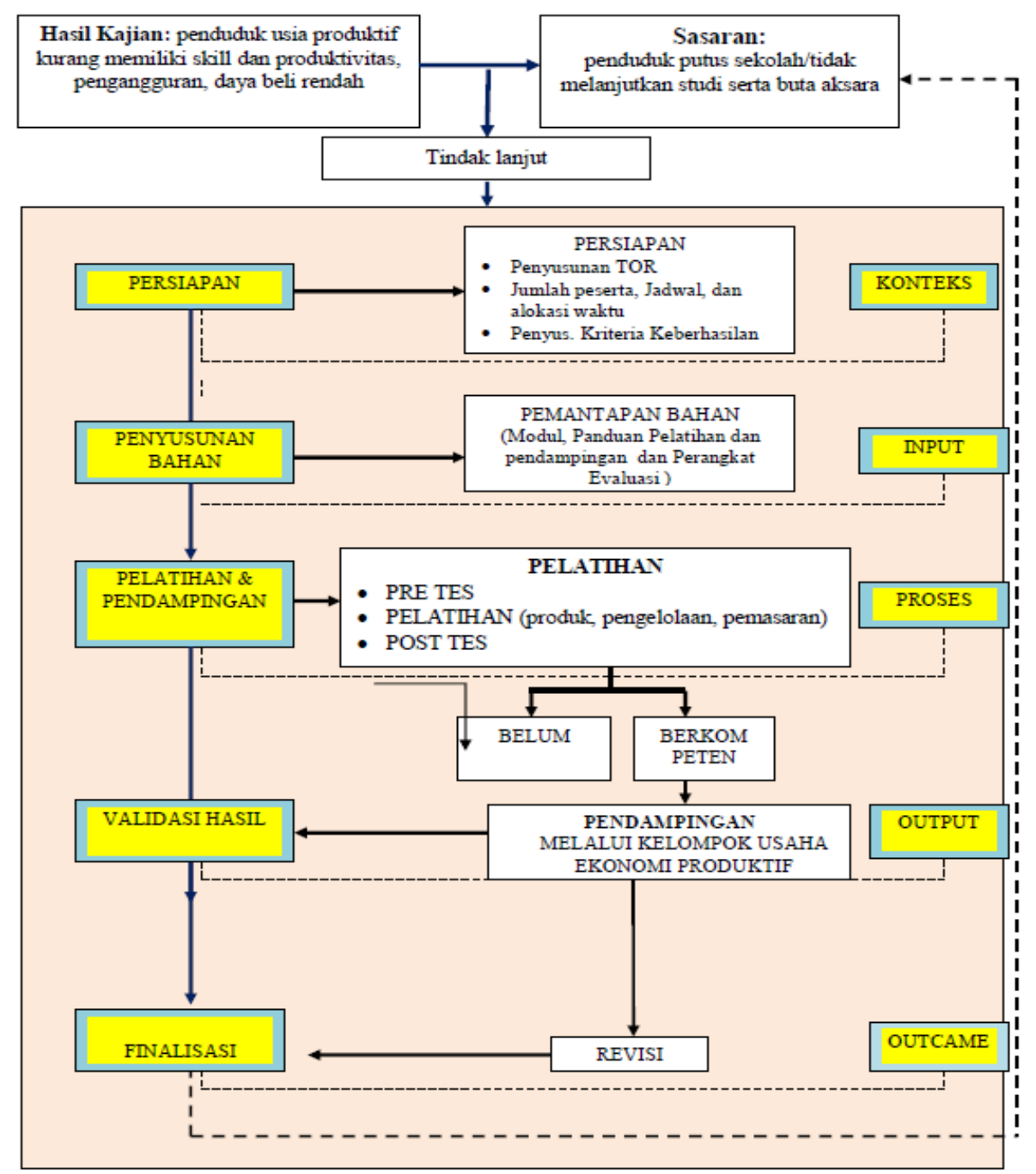

Gambar 1. Skenario Pengabdian 

berikut.

Skenario kegiatan dapat dijelaskan sebagai

1. Metode yang digunakan

Untuk kegiatan pelatihan dan pendampingan dilakukan dengan menggunakan metode Kaji Tindak Partisipatif pendekatan andragogis yang mengedepankan brainstorming dan melalui pelatihan serta pendampingan secara kolaboratif bersama khalayak sasaran. Paling tidak ada 2 kegiatan utama dalam pengabdian ini, yaitu: pelatihan melalui Demplot langsung dan pendampingan. Pola ini digunakan untuk meningkatkan kompetensi masyarakat dalam hal penguasaan: (a) pengembangan produk; (b) strategi pemasaran dan srategi bersaing produk; dan (c) penguasaan manajemen pengelolaan usaha. Untuk kegiatan pendampingan akan dilaksanakan secara tutorial pada saat masyarakat mengelola usaha ekonomi produktif dan kemitraan usaha kelompok sektor unggulan.

\section{Langkah Implementasi}

Untuk dapat menyelesaikan permasalahan utama dan untuk mencapai target luaran, maka ada beberapa tahapan implementasi sebagai berikut.

a. Tahap Persiapan, kegiatan yang dilakukan pada tahapan ini meliputi: koordinasi dengan kelompok sasaran (masyarakat), penentuan calon peserta, penentuan jadwal pelaksanaan pelatihan dan pendampingan, pemantapan materi pokok, penyusunan materi, penentuan alokasi waktu untuk setiap materi dan praktik, dan lainnya.

b. Tahap penyediaan bahan. Beberapa aktivitas yang dilakukan pada tahap ini yaitu penyusunan modul, paduan pelaksanaan kegiatan, dan lainnya.

c. Tahap Pelatihan. Kegiatan yang dilakukan pada tahapan ini antara lain memberikan pendidikan untuk memantapkan kompetensi masyarakat tentang tentang pengembangan produk, pengelolaan usaha, dan strategi pemasaran.

d. Pendampingan. Pada tahap ini dilakukan pendampingan secara kontinu, baik melalui tatap muka (tutorial) maupun melalui media sosial terhadap kerja masyarakat dalam pengembangan produk, strategi pemasaran, dan manajemen pengelolaan usaha yang dihasilkan memenuhi kelayakan.

e. Tahap validasi. Yang dimaksud tahap ini adalah berupa finalisasi model akhir pelatihan dan pendampingan usaha ekonomi produktif.

\section{Hasil dan Pembahasan}

Pemaparan deskripsi hasil pengabdian didasarkan atas tahapan pokok kegiatan pengabdian yang dilakukan, yaitu: hasil pelatihan dan pendampingan.

\section{Pelatihan Kewirausahaan}

Pelatihan kewirausahaan yang memenuhi kelayakan publikasi pada jurnal pengabdian dilaksanakan selama 1 (satu) hari dengan melibatkan sekitar 30 peserta masyarakat Desa Senyiur Kecamatan Keruak Kabupaten Lombok Timur. Kegiatan ini dilakukan pada hari Minggu, 14 April 2019. Beberapa temuan yang terekam selama proses pelatihan, seperti: (1) proses pelatihan berjalan sesuai dengan jadwal serta mekanisme yang ditentukan; (2) proses pelatihan dimulai dari pembukaan, sambutan Ketua Pelaksana, penyampaian materi oleh Tim. Penyampaian materi terbagi menjadi dua bagian besar, yaitu: pengembangan produk dan pengelolaan usaha. Perbandingan alokasi waktu adalah $40 \%$ teori dan $60 \%$ pelatihan; (3) selama proses pelatihan, peserta terlihat mengikuti dengan penuh semangat dan memberikan perhatian terhadap setiap materi yang disajikan, aktif bertanya dan berdiskusi, aktif meminta masukan dan saran terkait pelatihan kewirausahaan, aktif bertanya terkait trik pengembangan produk, pengelolaan usaha, strategi pemasaran, dan lainnya. Beberapa indikasinya adalah kegiatan pelatihan ini mendapatkan respon yang baik oleh peserta. Hal ini tidak lepas dari kebutuhan masyarakat untuk penguatan kompetensi dalam menghasilkan produk, mengelola usaha, dan srategi pemasaran produk sektor basis unggulan sehingga berimplikasi terhadap peningkatan pendapatan dan daya beli masyarakat.

Secara keseluruhan, peserta dapat memahami dan menguasai materi yang disajikan. Hasil uji melalui pertanyaan-pertanyaan yang diajukan oleh Tim mampu dijawab dengan baik. Selain itu, masyarakat berkomitmen dalam mengembangkan produk, pengelolaan usaha serta bagaimana pemasaran sesuai saran dan masukan dari Tim. Selain itu, peserta juga memahami dengan tepat pelatihan dalam pengembangan produk, pengelolaan usaha, strategi pemasaran dan strategi bersaing produk yang tepat karena hal tersebut menjadi krusial yang merupakan rohnya kewirausahaan. 


\section{Pendampingan}

Pendampingan pengelolaan usaha ekonomi produktif dan kemitraan usaha kelompok sektor unggulan ini dilakukan selama 3 (tiga) minggu untuk memastikan terkait tentang produksi, pemasaran, dan pengelolaan usaha. Pendampingan pengelolaan usaha misalnya, akan terkait dengan cara menata usaha berdasarkan manajemen modern, seperti manajemen usaha produktif. Penataan yang didampingi, antara lain: manajemen peluang, hubungan, mengorganisasi sumber daya, manajemen strategis, dan tata kelola keuangan. Pendampingan ini dilakukan melalui dua cara, yaitu: tatap muka dan online (media sosial). Tatap muka dilakukan mengingat sebagian peserta adalah masyarakat sekitar sehingga intensitas ke tempat pelatihan sangat tinggi. Namun demikian, jadwal pendampingan ini lebih cepat dari yang direncanakan, dikarenakan: (1) beberapa masyarakat sudah memiliki produk meskipun tingkat pemasaran masih jauh. Namun demikian, ketersediaan tersebut lebih memudahkan dalam memberikan bimbingan dan bantuan terutama dalam hal pengemasan; (2) masih cukup banyak masyarakat yang memiliki motivasi yang cukup tinggi, terutama kebutuhan untuk pengembangan produk, pengelolaan usaha, dan strategi pengemasan sehingga memudahkan dalam memberikan bantuan dan bimbingan.

Beberapa temuan yang terekam selama proses pendampingan adalah sebagai berikut: (1) terdapat peserta atau masyarakat Desa Senyiur Kecamatan Keruak Kabupaten Lombok Timur yang sudah mulai mengembangkan usaha, seperti peternakan dan pengemasan makanan hasil pertanian; (2) masing-masing kelompok masyarakat sudah berupaya melakukan perbaikan pengemasan produk berdasarkan pelatihan yang diikuti; dan (3) perbaikan juga banyak dilakukan terkait pengemasan produk.

Tim Pengabdian secara intensif memberikan perhatian, masukan, bimbingan, asistensi kepada masyarakat. Salah satu strategi yang digunakan adalah dengan melakukan komunikasi rutin melalui media sosial terkait kekurangan, kelemahan produksi, pengelolaan usaha dan strategi pemasaran dan lainnya. Hal ini dimaksudkan agar masyarakat secara terus menerus meningkatkan kualitas produksi dan pemasaran guna mempercepat peningkatan pendapatan dan daya beli masyarakat. Proses komunikasi dan dialog nampaknya memberikan efek positif terhadap perbaikan produksi dan pemasaran produk masyarakat.

Proses komunikasi dan dialog nampaknya memberikan efek positif pengembangan usaha masyarakat. Dialog ini memberikan efek terhadap semangat kelompok masyarakat untuk terus mengembangkan diri sesuai dengan kebutuhannya. Hal ini sejalan dengan pendapat Al-Hakim (2002) bahwa interaksi dan komunikasi menjadikan orang lain mengenal diri dan dunia lainnya termasuk dalam mengembangkan usaha produktif. Dialog, interaksi, dan komunikasi dengan kesetaraan akan berimplikasi terhadap keterbukaan dan kejujuran sehingga diketahui kelebihan dan kelemahannya (Al-Hakim , 2002). Komunikasi pula yang memiliki efek bagus terhadap produktivitas sebagaimana temuan Khairatun dkk. (2016). Proses interaksi atau dialog dan sinergi menjadi fondasi utama pembelajaran menurut teori rekonstruksi sosial, yang sangat efektif dalam mencapai perolehan kompetensi sebagaimana temuan-temuan Sukardi dkk. (2014) dan Sukardi (2016; 2017).

\section{Kesimpulan}

Dari paparan di atas, dapat disimpulkan sebagai berikut: (1) secara umum, masyarakat peserta pelatihan dan pendampingan pengembangan produk, pengelolaan usaha, dan strategi pemasaran sudah memiliki tambahan pemahaman dan kompetensi terkait dalam menghasilkan produk, mengelola usaha, dan srategi pemasaran produk sektor basis unggulan; (2) dibalik capain tersebut, hal yang perlu diapresiasi adalah adanya keinginan, semangat, dan motivasi peserta untuk terus berupaya mengembangkan produk sampai menghasilkan produk yang bisa bersaing. Selain dalam rangka menumbuhkan skill, pelatihan dan pendampingan ini berimplikasi terhadap peningkatan pendapatan dan daya beli masyarakat.

Berdasarkan simpulan tersebut, maka disarankan pada Lembaga Penelitian dan Pengabdian Pada Masyarakat untuk secara intensif melakukan bimbingan, arahan, pelatihan dan pendampingan kepada masyarakat untuk mempercepat pengembangan usaha ekonomi produktif. Saran secara khusus kepada Lembaga Penelitian dan Pengabdian Pada Masyarakat adalah agar memploting fasilitatator sesuai keahlian dengan produk masyarakat disamping 
diprioritaskan yang memiliki pengalaman dalam menghasilkan produk.

\section{Ucapan Terima Kasih}

Ucapan terima kasih disampaikan kepada Universitas Mataram, khsusnya Pascasarjana atas dukungan dan fasilitasi pelaksanaan pengabdian ini. Terima kasih pula disampaikan kepada Dewan Redaksi Jurnal Pendidikan dan Pengabdian Kepada Masyarakat atas perkenannya mempublikasikan hasil pengabdian ini.

\section{Daftar Pustaka}

Acs, Z.J., \& Amoros, J.E. 2008. Entrepreneurship and competitiveness dynamics in Latin America. Small Business Economics, 31 (3): 305-322.

Al-Hakim, S. 2004. Strategi Pembelajaran Berdasarkan Deep Dialogue. P3G, Dirjen Dikdasmen.

Badan Pusat Statistik Kabupaten Lombok Timur/BPS Lombok Timur. 2018a. Kecamatan Keruak dalam Angka 2018. Selong: BPS Kabupaten Lombok Timur.

Badan Pusat Statistik Kabupaten Lombok Timur/BPS Lombok. 2018b. Statistik Kabupaten Lombok Timur 2018. Selong: BPS Kabupaten Lombok Timur.

Etzkowitz, H., \& Zhou, C. 2008. Introduction to special issuebuilding the entrepreneurial university: A Global perspective. Science and Public Policy. 35 (9): 627-653.

Khairatun, L. I. K., Wilian, S., \& Sukardi. 2016. Pengaruh Kompetensi Kewirausahaan dan Keterampilan Berkomunikasi Terhadap Produktivitas Kerja Kepala Sekolah SMK/SMA/MA di Kabupaten Lombok Barat. Jurnal Praktisi Administrasi Pendidikan (JPAP), 1(1).

Koellinger, P.D., \& Thurik, A.R. 2012. Entrepreneurship and the business cycle. Review of Economics and Statistics, 94 (4): 1143-1156.

Lee, S.M., \& Peterson, S.J. 2000. Culture, entrepreneurial orientation, and global competitiveness. Journal of World Business, 35 (4): 401-416.
Pemerintahan Desa Senyiur. 2017. Profil Pemerintahan Desa Senyiur 2017. Senyiur: Pemerintahan Desa Senyiur.

Schulte, P. 2004. The Entrepreneurial university: A strategy for institutional development. Higher Education in Europe, 29 (2): 187191.

Sukardi, Ismail, M., \& Suryanti, N.M.N. 2014. Model Pendidikan kewirausahaan berbasis keterampilan lokal bagi anak putus sekolah pada masyarakat marginal. Cakrawala Pendidikan, 33 (3): 402-412.

Sukardi. 2010. Kondisi Anak tidak dan atau Putus Sekolah Jenjang Pendidikan Dasar pada Masyarakat di NTB: Ke Arah Percepatan Penuntasan Wajib Belajar 9 Tahun. Makalah disajikan dalam Simposium Nasional Kebijakan dan Inovasi Pendidikan, Balitbang Depdiknas, Jakarta, 2-4 Agustus.

Sukardi. 2017. Efektivitas Model Prakarya dan Kewirausahaan Berbasis Ekonomi Kreatif Berdimensi Keunggulan Lokal Terhadap Keinovatifan Siswa. Cakrawala Pendidikacsan, 36 (2): 267-279.

Wong, P.K. Ho, Y.P., \& Autio, E. 2005. Entrepreneurship, innovation and economic growth: Evidence from GEM data. Small Business Economics, 24 (3): 335-350.

Wong, P.K. Ho, Y.P., \& Singh, A. 2007. Toward an "entrepreneurial university" model to support knowledge-based economic development: The case of the National University of Singapore. World Development, 35 (6): 941-958.

Zimmerer, T.W., Scarborough, N.M. \& Widson, D. 2008. Essentials of Entrepreneurship and Small Business Management ( $5^{\text {th }}$ ed). Upper Saddle rever, NJ: Pearson Education, Inc. 